\title{
Beach seine fisheries in Badagry, Lagos State, South West, Nigeria
}

\author{
Martins A. Anetekhai*, Olusegun 0. Whenu, Oluwayemisi A. \\ Osodein and Abdsomad 0. Fasasi
}

Department of Fisheries, Lagos State University, Lagos, Nigeria. Email: anetekhaimartins@gmail.com.

\begin{abstract}
Beach seine fisheries in Badagry, Lagos State, Nigeria, was studied. Focused group discussion, observation and interview sessions were used to collect data on gear description, catch composition, socio-economic characteristics, livelihood parameters, fish species, productivity and other fishing inputs. Surveyed beach seine net had mean length of $301.76 \mathrm{~m} \pm 17.82$ $\mathrm{m}$ while the depth of the wing and at the centre measured 2.80 $\mathrm{m} \pm 0.14 \mathrm{~m}$ and $4.02 \mathrm{~m} \pm 0.22 \mathrm{~m}$, respectively. The mean of the frequency of operation for the fishing companies was highest in April (22.20 \pm 1.49$)$ and the lowest in September (13.20 \pm 0.86$)$. The moon fish (Carangidae), croaker fish (Scianidae) and spadefish (Eppiphidae) families represented more than half of the daily landings. The mean monthly catch recorded for the companies ranged from minimum of $644.50 \mathrm{~kg} \pm 98.72 \mathrm{~kg}$ to maximum of $754.03 \mathrm{~kg} \pm 123.523 \mathrm{~kg}$ from April to September with the market price for fish (in Nigerian Naira that ranged from $\$ 3.18$ to $\$ 15.91$ per basin and recorded highest biannual mean income of $\$ 780.72 \pm \$ 67.00 .20 \%$ of the respondents were aged between 21 and 30 years followed by $37 \%$ of those aged between 31 to 40 years while $29 \%$ were aged between 41 to 50 years and $12 \%$ were between 51 to 60 years old. Only $2 \%$ were above 61 years of age which shows the years of experience of the fisher folks. Of the total 50 respondents, $94 \%$ were found to be males while $6 \%$ were females. Larger proportions of the fisher folks (36\%) were single, $56 \%$ were married and $8 \%$ were divorced. The distribution of level of education shows that about $21 \%$ of the fishermen, who were involved in beach seine fisheries, had no formal education, while $40 \%$ had primary education, $34 \%$ had secondary education and only $5 \%$ had tertiary education. The coastal artisanal fishery is still able to absorb a little more effort and capacity to enable production meet up with the potential yield. It is however essential in the national interest that there should be a clear understanding of fishing capacity development on capital, labour and fish resources, both in the short and long term.
\end{abstract}

Keywords: Beach seine fishing; Artisanal fisheries; Beach seine net; Sociodemographic analysis; Food security.
Received

September 4, 2018

Accepted

November 23, 2018

Released

December 31, 2018

Full Text Article

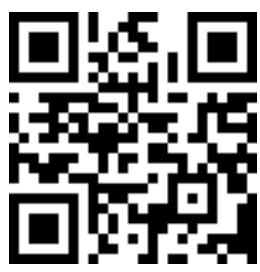

ORCID

D) 0000-0001-5969-7832

Martins A. Anetekhai

(D) 0000-0002-8875-5269

Olusegun 0 . Whenu

(1) 0000-0002-1472-956X

Oluwayemisi A.

Osodein

(ㄱ) 0000-0001-8904-4058

Abdsomad 0. Fasasi 


\section{Introduction}

Nigeria is blessed with inland water, brackish water, and marine water fisheries resources. On the basis of her resources, fisheries can be broadly classified into: Artisanal fisheries (85\%), industrial fisheries (14\%), and culture fisheries (1\%) (FDF, 2005). Fishing is an ancient human tradition involving the hunting and gathering of aquatic products for food. Fish represent a major food source, which is invaluable for the protein they provide and the industrial products they produce. Fish is also economically, socially and culturally important as a global dietary aspect of sustainable food security. Economically fish provides an important source of food and income for both men and women and fishing has an important social and cultural position in riverine communities.

Lagos State is situated along the vast coastline which is endowed with marine, brackish and fresh waters of varying ecological zones and numerous fish species. Survey shows that Lagos State harbours 30,000 actively engaged fish farmers with manual gears and craft types. Atlantic Ocean, Lagos State has a morphology comprising of about $78 \%$ water bodies of various extensive network of lagoons, lakes, streams and wetlands (Lagos State Gazette, 2009). The Lagos State fisher folks operate from small, scattered coastal communities using the "Ghana" plank boats, traditional half dug-out canoes and traditional smaller plank canoes. The use of outboard engine and type of net depends on the type of fishery operated. Badagry is an active fishing settlement located on the shoreline. "Eguns" and Ghanaian speaking fishers are found in Badagry.

Badagry is a coastal town and Local Government Area (LGA) in Lagos State, Nigeria. It is situated between the city of Lagos, and the border with Benin at Seme. As of the preliminary 2006 census results, the municipality had a population of 241,093 (Federal Republic of Nigeria Official Gazette, 2007) .The fishing settlements are due to the water mass present in the area of Badagry. Small-scale fisheries can be broadly characterized as a dynamic and evolving sector employing labour, intensive harvesting, processing and distribution technologies to exploit marine and inland water fishery resources. The activities of this sub-sector, conducted fulltime or par time, or just seasonally, are often targeted on supplying fish and fishery products to local and domestic markets, and for subsistence consumption (FAO, 2005). Different form of fishing gears are used by Fishermen in Badagry which include beach seine, gillnets, traps, hooks and lines and so on.

Seining is a fishing technique traditionally done in areas with large schools or groups of fish. The earliest form of seining was beach seining (DOGBO). There is evidence of seine nets used in artisanal fisheries several thousands of years ago and on every continent, including North America (Brandt, 1984).

Beach seine nets have been used in fisheries for several thousand years and on every Continent (Gabriel et al., 2005). The ancient Phoenicians and Romans employed beach seining to catch fish in the Mediterranean. A typical beach seine has weights attached to the lead line at the bottom of the net and buoys or floats attached to the float line at the top of the net. The downward force of the weights counteracted by the buoyancy of the floats keeps the net open vertically when it is pulled through the water to entrap fish. A beach seine is often set from shore to encircle a school of fish. Beach seines can also be set at some distance from and parallel to the shore, though still in shallow water, and then hauled onto a boat. This latter method evolved historically into the development of what are now called purse seines, lampara and ring nets.

Typically, two types of beach seines were used, beach seines with cod end and those without cod end. In the 
case of beach seines without cod end, the central section of the seine consisted of loose netting. The typical beach seine consists of a seine body (or central section) and cod end, to which anterior and posterior wings are attached. The gear has a head rope (also referred to as float line) with floats to keep the upper part of the seine on the surface, and a footrope (also referred to as lead line) with sinkers to keep the gear on or close to the bottom and prevent fish from escaping from the area enclosed by the seine. Hauling ropes or warps are attached to both ends of the wings of the seine. The longer the hauling lines and the wings are, the larger is the fishing area that could be covered with the seine.

In most cases, non-motorized boats are used to set the seine; however, motorized boats are also used. When setting the beach seine, one of the hauling lines is fastened onto the shore, and the shoreward wing, seine body and seaward wing are set out in a wide semicircular arc. Once the entire net is in the water, the second hauling rope is brought back to the shore. The hauling ropes are then hauled in simultaneously to the beach. The hauling may be done either manually or by means of a tractor, vehicle or winch. The long hauling ropes and the wings of the seine herd fish into the centre part of the seine body. Target species include pelagic as well as demersal species.

The beach seine is set counter current curve with Ghanaian type boat in the morning when the ocean is calm. The boat is attached to the hauling rope and forms a semi-circle and brings to the other side of the beach. The wings have a rope at the top with floats and at the bottom with lead sinkers whereby the net covers the area from the water surface down to the ocean floor. After some time this will become an arch by first hauling by one side of the rope and then pulling both ropes simultaneously to drag the net to the shore, leaving the enclosed fish no other option than to swim into the cod end. This can be done by ten to fifteen people.

Hauling is done at beach shore with fifteen to forty men who engage in the hauling. With a large net there can be almost thirty or forty people pulling on each side (Figure 1). During the process, the two groups will gradually walk towards each other which can take three to seven hours, depending on the number of ropes used (also depends on the size of the net).

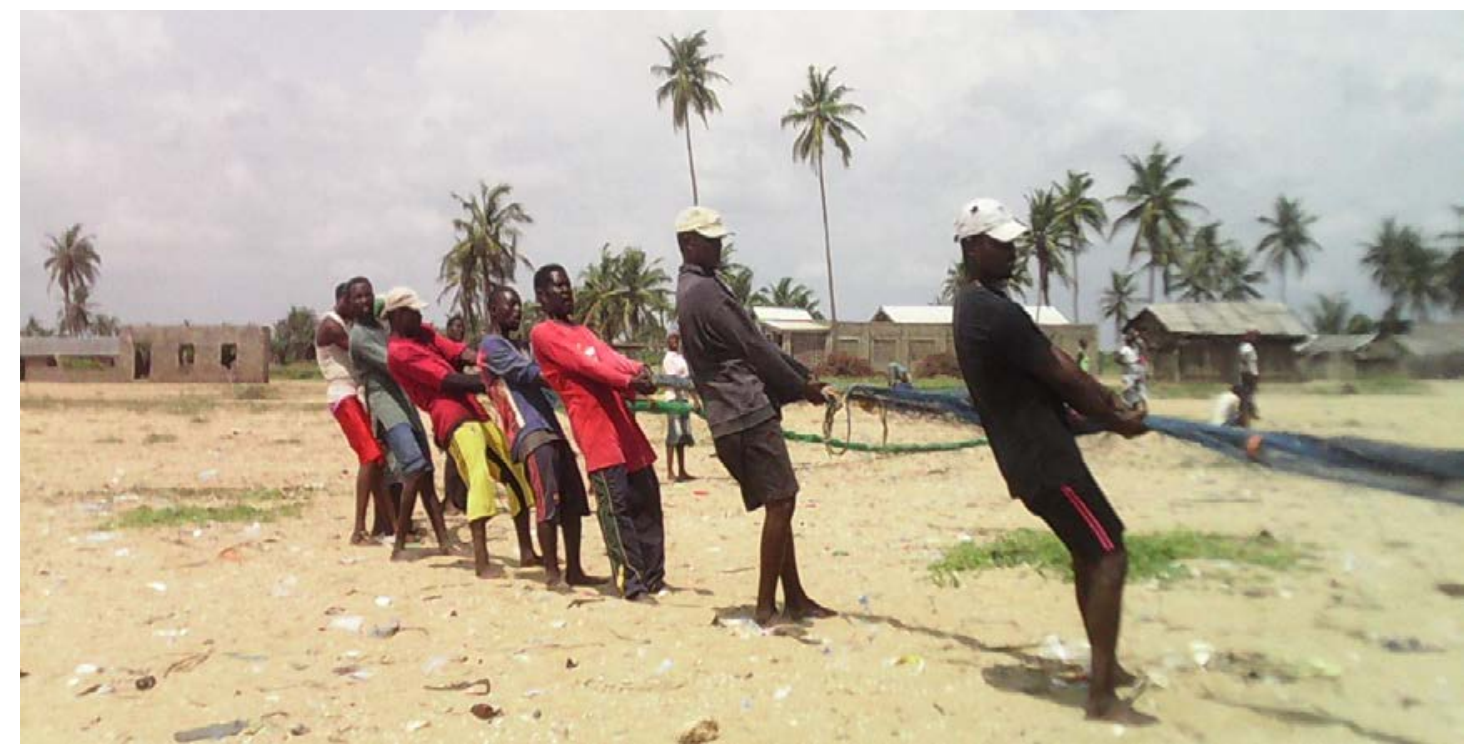

Figure 1. Fishermen hauling the beach seine manually. 
Many crew members have a piece of cloth that they wind round the (wet) rope to protect their hands. As they pull, you can see their bodies hanging back, putting their full weight into the action. Music and rhythm are an important part of beach seine fishing in Badagry. The fishermen sing while pulling on the beach. The nets are crossed in order to enclose the fish making the two wings to be put together and hauled in as one (Figure 2).

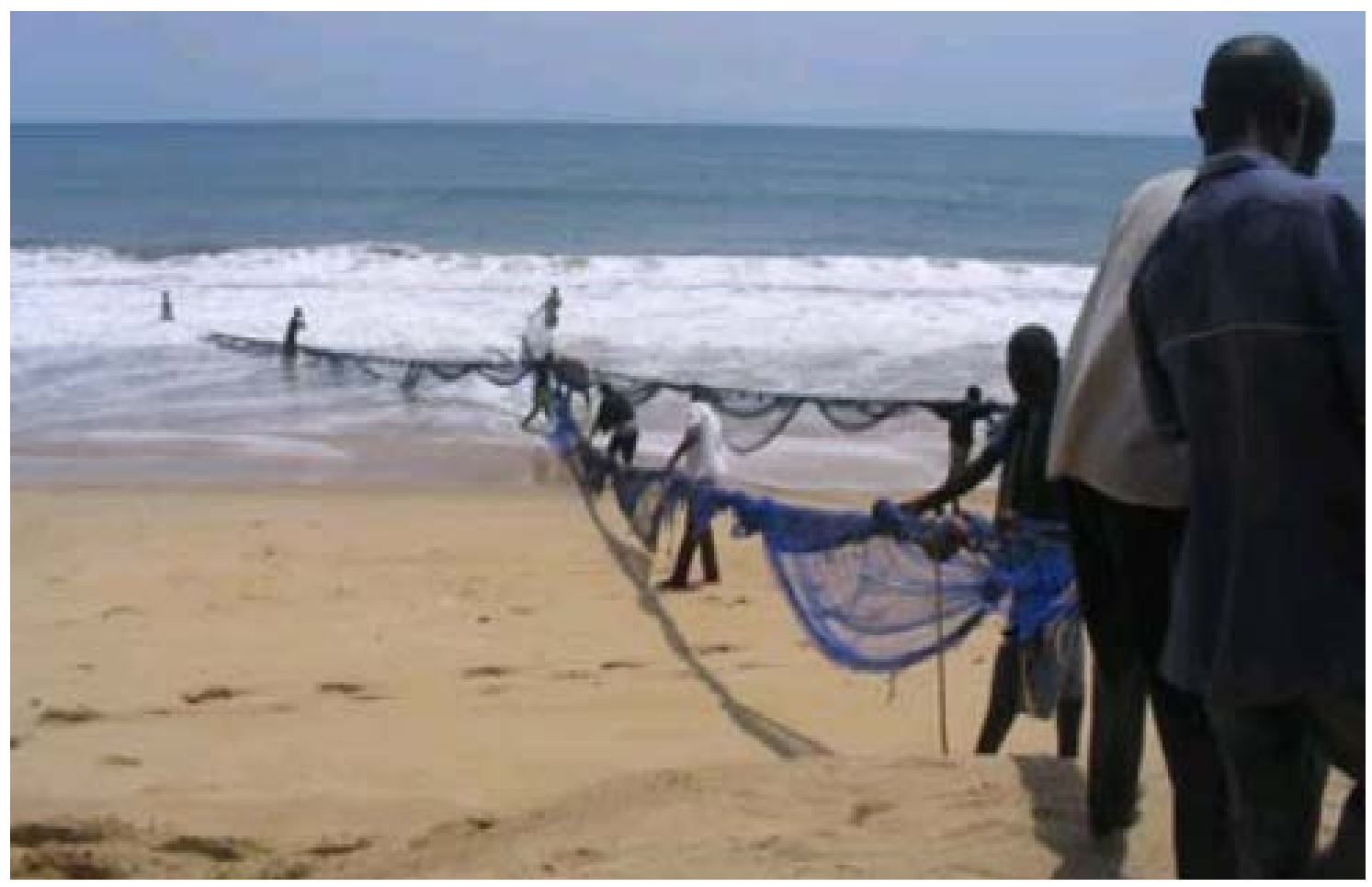

Figure 2. The net was brought close and hauled as one.

The two groups of people pulling on each side of the net now come together. After the cord end has been landed, the cod end is emptied by filling the basins of the women who will later buy the fish after it has been divided into heaps. Not all of the fish are for sale, some will be given to the people who came to help while the big fish will be put aside to share with the company members (only if the catch is big enough) and the rest will be sold.

At least once a year, the net is overhauled. This means that the lead sinkers and floats are put back in a balanced position. Every part of the beach seine is studied. But regular maintenance of the net is done on the ropes, the cod end, the length of the net, the amount of lead, and the position of the floaters (Figure 3). 


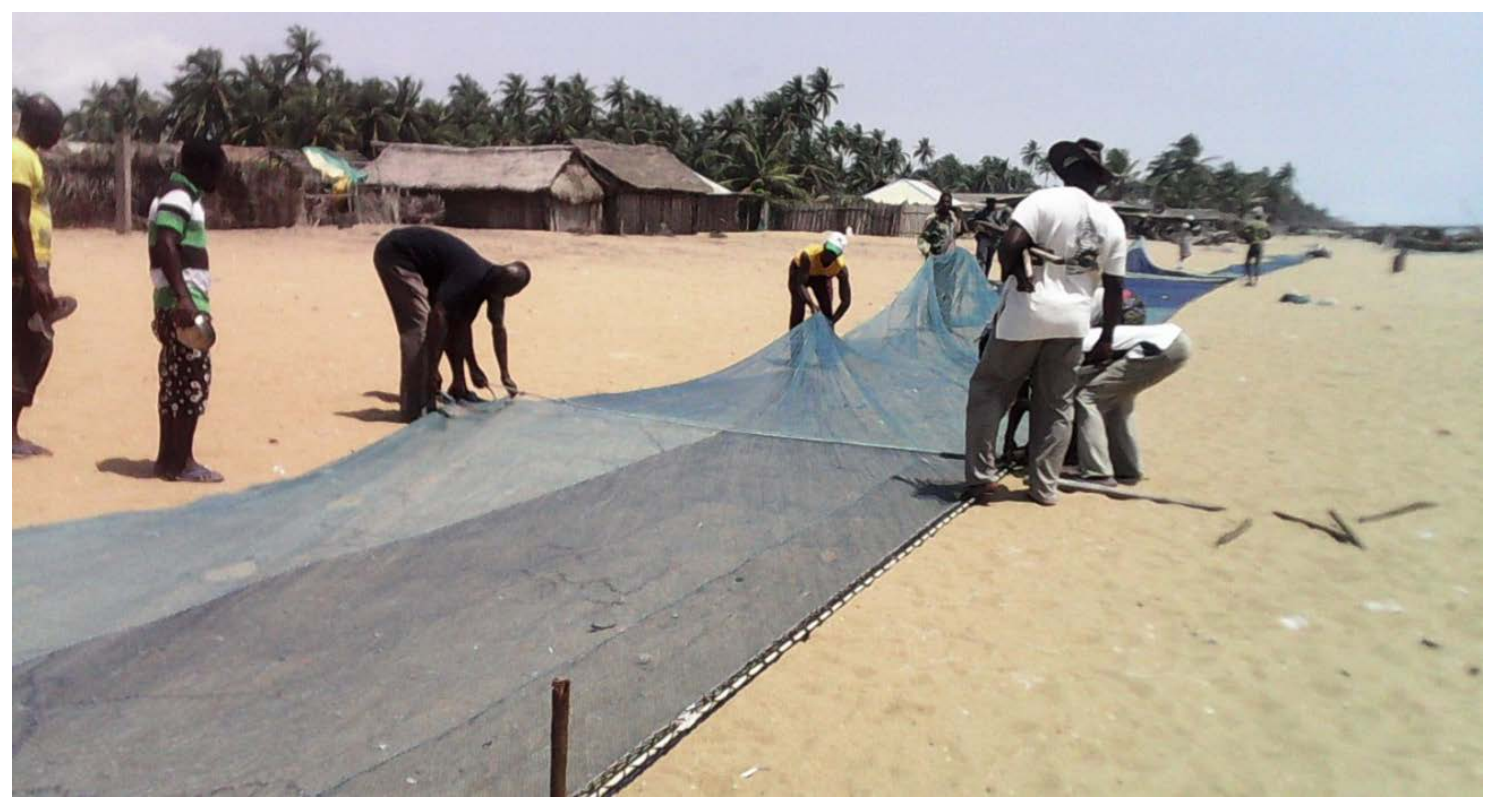

Figure 3. Maintenance of the beach seine net in preparation for fishing.

\section{Materials and methods}

\section{Area of the study}

The study was carried out in Badagry divisions of Lagos State between April to September, 2015, with coordinates $6^{0} 25 \mathrm{~N} \mathrm{2053/6.42^{0 } 6 7 ^ { \circ } \mathrm { N }}$ $2.88^{\circ} \mathrm{E}$ either the use of map or coordinate, a state created on May 27, 1967 by virtue of State (Creation and Transitional Provisions) Decree No. 14 of 1967, which restructured Nigeria's Federation into 12 States. It shares boundaries with Ogun State both in the North and East and is bounded on the west by the Republic of Benin. In the South it stretches for 180 kilometres along the coast of the Atlantic Ocean. The smallest state in the Federation, it occupies an area of 3,577 sq. $\mathrm{km} .22 \%$ or $787 \mathrm{sq} . \mathrm{km}$ of which consists of lagoons and creeks. Lagos State has 20 Local Government Areas (LGAs) and it is described as the nation's commercial hub. Fishery activities are concentrated in Gberefu, Aivoji, Asakpo, Daloko, Yovoyan, Gbaragada, Konfidame, Ilaje, Hungbo and Ajido. Primary data were used to achieve the objective of the study. The instrument used to obtain data was through pre-test, wellstructured and validated interview schedule directed at the artisanal fishermen in Badagry Area of Lagos State. Fishing companies used for the study are Baba Agba Fishing Company, Kwami-Kotokpa Fishing Company, Hope Fishing Company at Asakpo, Mr Yovoyan Fishing Company, and Boglo Fishing Company.

\section{Data collection}

Both primary and secondary sources of data were used in collating the data for the study. The primary sources include the interview guide and from personal communication with the fisher folks and anchor men. The secondary sources of data were from past related research reports, text books and information from government establishments. Data were also collected from beach seine owners and their crew members with the use of personal interview, complete enumeration and direct observations. 


\section{Ecological indices}

The following ecological indices measures were computed using COPY PAST SOFTWARE.

Number of species, species diversity, richness and evenness of abundance for each monthly catch combination over the study period.

a) Richness Index = A measure of species diversity calculated as $\mathrm{d}=(\mathrm{S}-1) / \mathrm{ln} \mathrm{N}$. Where $S=$ number of species in the habitat or community, and $\mathrm{N}=$ the total number of individuals of all species.

b) Shannon-Weiner (1963) information function ' $H$ ' $=-\sum$ pi log pi; where pi is the proportion of the $i^{\text {th }}$ species in the sample.

c) Simpson's Index (D) = An index of diversity based on the probability of picking two organisms at random that are different species; calculated as $\mathrm{D}=$ $1-\sum\left(\mathrm{Pi}^{2}\right)$; where $\mathrm{Pi}=$ the proportion of individuals of species I in a community of $s$ species.

d) Evenness of distribution. $E=H / \log _{2} S$. Where $S$ is the number of species (taxa), $H$ is the Shannon-Weiner index of diversity and $\mathrm{E}=$ Measure of evenness having a maximum value of 1 when all species regardless of their number are present in equal proportions.

\section{Data analysis}

The data was analyzed statistically with SPPS IBM version 20.0. Fish production, catch composition in the five fishing Communities. The total fish production and the money value were equally computed.Focus group discussion, beach observation and direct interviews were conducted for the study from April to September 2016. Physical observation of fish landing, Fish samples were collected at random from beach seine companies along the ocean coast during the study period and identification was done with fish base site, counting and identification of types of fishing canoes at the beaches were made.

\section{Results}

\section{company}

Gear description for each

The size of the beach seine depends on the number of pieces joined, depth of operation, number of fisher and at times number of people to haul the rope. A majority of the surveyed beach seine had length of varying from $250 \mathrm{~m}$ to $350 \mathrm{~m}$ the depth at wing varying from $2.44 \mathrm{~m}$ to $3.05 \mathrm{~m}$ while the depth at the centre vary from $3.66 \mathrm{~m}$ to $4.58 \mathrm{~m}$. The mesh size tapered towards the cod end at different part of the net. The fore wings had the larger mesh size ranging from 50 $\mathrm{m}$ to $60 \mathrm{~mm}$. The body had mesh sizes varying from $25 \mathrm{~m}$ to $30 \mathrm{~mm}$ while the cod end had finer mesh of $8 \mathrm{~m}$ to $12 \mathrm{~mm}$. The bag portions were long, but the majority ranged between $10 \mathrm{~m}$ to $20 \mathrm{~m}$ with a depth of $6 \mathrm{~m}$ (Table 1).

Table 1. Gear description for each company

\begin{tabular}{|c|c|c|c|c|c|c|}
\hline \multirow{2}{*}{ Fishing companies } & \multirow{2}{*}{$\begin{array}{l}\text { Length } \\
\text { (m) }\end{array}$} & \multicolumn{2}{|c|}{ Depth (m) } & \multirow{2}{*}{$\begin{array}{l}\text { Fore wing } \\
\text { Mesh size } \\
\text { (mm) }\end{array}$} & \multirow{2}{*}{$\begin{array}{c}\text { Body mesh } \\
\text { size } \\
(\mathrm{mm})\end{array}$} & \multirow{2}{*}{$\begin{array}{l}\text { Cod } \\
\text { end } \\
(\mathrm{mm})\end{array}$} \\
\hline & & Wing & Centre & & & \\
\hline $\begin{array}{l}\text { Baba Agba Fishing } \\
\text { Company }\end{array}$ & 250 & 2.44 & 3.66 & 50 & 25 & 10 \\
\hline $\begin{array}{l}\text { Kwami Kotokpa Fishing } \\
\text { Company }\end{array}$ & 340.61 & 3.05 & 4.58 & 50 & 25 & 10 \\
\hline $\begin{array}{l}\text { Hope Fishing Company at } \\
\text { Asakpo }\end{array}$ & 320 & 3.05 & 3.66 & 50 & 25 & 10 \\
\hline $\begin{array}{l}\text { Mr Yovoyan Fishing } \\
\text { Company }\end{array}$ & 350 & 3.05 & 4.58 & 60 & 30 & 12 \\
\hline Boglo Fishing Company & 300 & 2.45 & 3.66 & 50 & 25 & 8 \\
\hline
\end{tabular}


The mean length of the beach seine net was $301.76 \mathrm{~m} \pm 17.82 \mathrm{~m}$ as shown in Table 2 . The depth of the net at the wing was $4.02 \mathrm{~m} \pm 0.14 \mathrm{~m}$ while is $4.02 \mathrm{~m} \pm 0.22 \mathrm{~m}$ at the centre. The mesh size of the body was $26.00 \mathrm{~mm} \pm 1.00$ $\mathrm{mm}$. The fore wing and cod end mesh sizes were $50.00 \mathrm{~mm} \pm 2.00 \mathrm{~mm}$ and 10.0 $\mathrm{mm} \pm 0.63 \mathrm{~mm}$, respectively (Table 2).

Table 2. Minimum value, maximum values, mean value and standard error of beach seine net description.

\begin{tabular}{lccc}
\hline Dimension & Minimum & Maximum & Mean \pm SE \\
\hline Length $(\mathrm{m})$ & 250 & 350 & $301.76 \pm 17.82$ \\
Depth wing (m) & 2.44 & 3.05 & $2.80 \pm 0.14$ \\
Depth center (m) & 3.66 & 4.58 & $4.02 \pm 0.22$ \\
Fore wing mesh size (mm) & 50 & 60 & $50.00 \pm 2.00$ \\
Body mesh size (mm) & 25 & 30 & $26.00 \pm 1.00$ \\
Cod end mesh size (mm) & 8 & 12 & $10.00 \pm 0.63$ \\
\hline
\end{tabular}

Mr Yovoyan Fishing Company had the longest beach seine net in Badagry of $350 \mathrm{~m}$ followed by Kwami Kotokpa $340.61 \mathrm{~m}$, but both companies had the same depth of $3.05 \mathrm{~m}$ at the wing and $4.58 \mathrm{~m}$ at the centre. Baba Agba Fishing Company had the shortest beach seine net of $250 \mathrm{~m}$ with $2.44 \mathrm{~m}$ wing depth and $3.66 \mathrm{~m}$ at the centre.
All the fishing companies except Mr Yovoyan Fishing Company had the same fore wing and body mesh sizes of $50 \mathrm{~mm}$ and $25 \mathrm{~mm}$, respectively. $\mathrm{Mr}$ Yovoyan Fishing Company had fore wing size of $60 \mathrm{~mm}$, body mesh size of $30 \mathrm{~mm}$ and cod end mesh size of $12 \mathrm{~mm}$ (Figure 5).

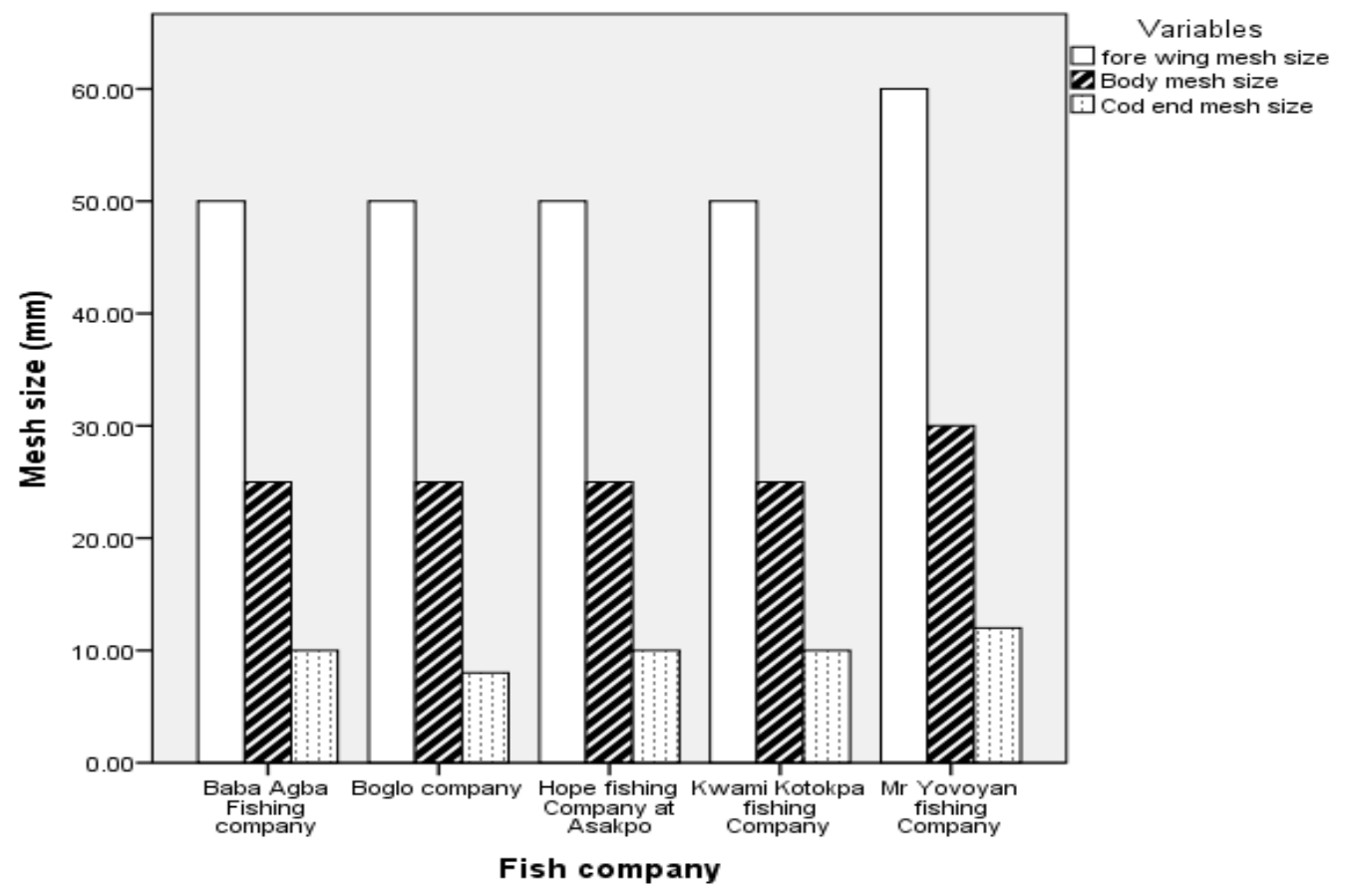

Figure 5. Mesh size of the beach seine net for each company. 


\section{Beach seine catch composition}

Beach seine catch composition is the compilation of types of fishes encountered through observation of landing operations of the beach seine fishing companies in Badagry. The fishes' family names as the species identified were inexhaustible. Fishers targeted commercially important species for the purpose of recouping their costs. Beach seine catch composition for in the study area were shown in table 3 , comprising of 24 families and 43 species and their common name. Identification was done using fish base site.

Table 3. Observed species of the beach seine catch composition.

\begin{tabular}{|c|c|c|}
\hline Family & Species & Common name \\
\hline Aridae & Arius gigas & Giant catfish \\
\hline Albulidae & Albula vulpes & Bonefish \\
\hline Balistidae & Balistes patusunct & Trigger fish \\
\hline Bothidae & Syacium micrurum & Channel flounder \\
\hline \multirow[t]{7}{*}{ Carangidae } & Alectis alexandrines & Alexandria pompano \\
\hline & Caranx crysos & Blue runner \\
\hline & Chloroscombrus chrysurus & Atlantic bumper \\
\hline & Decapterus punctatus & Round scad \\
\hline & Selene dorsalis & African moonfish \\
\hline & Seriola dumerili & Greater amberjack \\
\hline & Trachurus trecae & Horse mackerel \\
\hline \multirow[t]{3}{*}{ Clupeidae } & Ilisha Africana & West African ilisha \\
\hline & Sardinella aurita & Round sardinella \\
\hline & Sardinella maderensis & Madeiran sardinella \\
\hline \multirow[t]{3}{*}{ Cynoglossidae (Sole) } & Cynoglossus senegalensis & Senegalese tonguesole \\
\hline & Cynoglossus browni & Nigerian tonguesole \\
\hline & Cynuglossus canariensis & Canary tonguesole \\
\hline Dasyatidae & Dasyatis centroura & Stingray \\
\hline Drepanidae & Drepana Africana & African sicklefish \\
\hline Engraulididae & Engraulis encrasicolus & European anchovy \\
\hline Ephippidae & Chaetodipterus faber & Atlantic spade fish \\
\hline Exocoetidae & Hirundicthys speculiger & Mirrorwing flyingfish \\
\hline \multirow[t]{2}{*}{ Hemiramphidae } & Hemiramphus balao & Balao half beak \\
\hline & Oxyporhamphus micropterus & False halfbeak \\
\hline \multirow[t]{2}{*}{ Lutjanidae } & Apsilus fuscus & African forktail snapper \\
\hline & Lutjanus agennes & African red snapper \\
\hline Mugilidae & Mugil cephalus & Flathead grey mullet \\
\hline Mullidae & Pseudupenus prayensis & West African goatfish \\
\hline \multirow[t]{3}{*}{ Polynemidae } & Galeoides decadactylus & African threadfin \\
\hline & Pentanemus quinquarius & Royal threadfin \\
\hline & Polydactylus quadrifilis & African threadfin \\
\hline \multirow[t]{2}{*}{ Haemulidae } & Brachydeuterus auritus & Big eye grunt \\
\hline & Pomadysis jubelini & Sompat grunt \\
\hline \multirow[t]{4}{*}{ Sciaenidae } & Pseudotolithus elongates & Bobo croaker \\
\hline & Pseudotolithus senegalis & Cassava croaker \\
\hline & Pseudotolithus typus & Croaker \\
\hline & Pteroscion peli & Boe drum \\
\hline Sphyraenidae & Sphyraena sphyraena & Barracuda \\
\hline Trichiuridae & Trichiurus lepturus & Largehead hairtail \\
\hline Rajidae & & Ray fish \\
\hline Portunidae & Callinectis amnicola & Bigfisted swimcrab \\
\hline \multirow[t]{2}{*}{ Penaeidae } & Parapenaeus longirostris & Deepwater rose shrimp \\
\hline & Penaeus notialis & Pink shrimp \\
\hline
\end{tabular}


Aridae was identified in all the landings during the period of sampling, only one species was identified. Arius gigas was common to the companies from the catches of the Baba Agba Fishing Company, Kwami Kotokpa
Fishing Company, Hope Fishing Company, Mr Yovoyan Fishing Company and Boglo Fishing Company (Table 4). The species had high relative abundance with Evenness index of one. But there was relatively low diversity.

Table 4. The ecological indices of the species composition of Family Aridae.

\begin{tabular}{lcccccc}
\hline & April & May & June & July & August & September \\
\hline Species & 1 & 1 & 1 & 1 & 1 & 1 \\
Individuals & 43 & 31 & 15 & 19 & 5 & 6 \\
Dominance D & 1 & 1 & 1 & 1 & 1 & 1 \\
Shannon H & 0 & 0 & 0 & 0 & 0 & 0 \\
Simpson 1-D & 0 & 0 & 0 & 0 & 0 & 0 \\
Evenness e^H/S & 1 & 1 & 1 & 1 & 1 & 1 \\
Margalef & 0 & 0 & 0 & 0 & 0 & 0 \\
\hline
\end{tabular}

The ecological indices of Family Balistidae with single species are less diverse in the study area and the relative abundance is high. Balistes patusunct was not found in April, but it was found in May, June, July, August and September in all the catches of the fishing companies. The species had high relative abundance with Evenness index of one. But there was relatively low diversity with Shannon's index and Simpson's index of zero (Table 5).

Table 5. The ecological indices of the species composition of Family Balistidae.

\begin{tabular}{lccccc}
\hline & April & May & June & July & September \\
\hline Species & 0 & 1 & 1 & 1 & 1 \\
Individuals & 2 & 4 & 7 & 6 & 3 \\
Dominance D & 1 & 1 & 1 & 1 & 1 \\
Shannon H & 0 & 0 & 0 & 0 & 0 \\
Simpson 1-D & 0 & 0 & 0 & 0 & 0 \\
Evenness e^H/S & 1 & 1 & 1 & 1 & 1 \\
Margalef & 0 & 0 & 0 & 0 & 0 \\
\hline
\end{tabular}

The Family Carangidae was dominant family in the study area. Shannon diversity index showed that the family were well diverse in the landings of the fishing companies Simpson's index showed that the family were infinitely diverse with 0.74 in April, 0.72 in May, 0.73 in June, 0.77 in July, 0.70 in August, and 0.75 in September. The specie was more dominant than most other family (Table 6). 
Table 6. The ecological indices of the species composition for Family Carangidae.

\begin{tabular}{lcccccc}
\hline & April & May & June & July & August & September \\
\hline Species & 9 & 10 & 10 & 7 & 8 & 6 \\
Individuals & 225 & 541 & 691 & 461 & 312 & 189 \\
Dominance_D & 0.26 & 0.2836 & 0.2615 & 0.2233 & 0.2919 & 0.2468 \\
Shannon H & 1.528 & 1.545 & 1.613 & 1.598 & 1.464 & 1.528 \\
Simpson1-D & 0.74 & 0.7164 & 0.7385 & 0.7767 & 0.7081 & 0.7532 \\
Evenness_e^H/S & 0.5119 & 0.4686 & 0.5016 & 0.706 & 0.5404 & 0.7681 \\
Margalef & 1.477 & 1.43 & 1.377 & 0.9783 & 1.219 & 0.9539 \\
\hline
\end{tabular}

The presence of the species in the fishing of the beach seine fishers in Badagry during the period of the study. Three specie were observed during the study with a very high biodiversity and a relatively high abundance with Evenness index from April to September 0.9585 to 0.7891 . The Shannon diversity indexes from April to September were 1.056, $0.8977,0.9684,0.8864,1.039$ and 0.8618 (Table 7).

Table 7. The ecological indices of the species composition for Family Cynglosidae.

\begin{tabular}{lcccccc}
\hline & April & May & June & July & August & September \\
\hline Species & 3 & 3 & 3 & 3 & 3 & 3 \\
Individuals & 157 & 153 & 254 & 181 & 88 & 81 \\
Dominance_D & 0.3611 & 0.4506 & 0.4189 & 0.4548 & 0.3753 & 0.4955 \\
Shannon_H & 1.056 & 0.8977 & 0.9684 & 0.8864 & 1.039 & 0.8618 \\
Simpson 1-D & 0.6389 & 0.5494 & 0.5811 & 0.5452 & 0.6247 & 0.5045 \\
Evenness_e^H/S & 0.9585 & 0.818 & 0.8779 & 0.8088 & 0.9423 & 0.7891 \\
Margalef & 0.3956 & 0.3976 & 0.3612 & 0.3847 & 0.4467 & 0.4551 \\
\hline
\end{tabular}

Only single species of Dayastidae Dasyatis centroura was observed in the catches of the beach seine fisher from April to May. There is relatively high abundance of the species but were less diverse with Evenness index of one and Shannon diversity to be zero (Table 8).

Table 8. The ecological indices of the species composition of Family Dasyastidae.

\begin{tabular}{lcccccc}
\hline & April & May & June & July & August & September \\
\hline Species & 1 & 1 & 1 & 1 & 1 & 1 \\
Individuals & 12 & 9 & 32 & 32 & 13 & 5 \\
Dominance_D & 1 & 1 & 1 & 1 & 1 & 1 \\
Shannon_H & 0 & 0 & 0 & 0 & 0 & 0 \\
Simpson_1-D & 0 & 0 & 0 & 0 & 0 & 0 \\
Evenness_e^H/S & 1 & 1 & 1 & 1 & 1 & 1 \\
Margalef & 0 & 0 & 0 & 0 & 0 & 0 \\
\hline
\end{tabular}


The relative abundance of Family Sphyraenidae is relative high with Evenness index of 1 throughout the period of the study. But the species are less diverse with Shannon diversity index of 0 from April to September. Sphyreanae sphyreanae was the only species found in the beach seine catches (Table 9).

Table 9. The ecological indices of the species composition of Family Sphyraenidae.

\begin{tabular}{lcccccc}
\hline & April & May & June & July & August & September \\
\hline Species & 1 & 1 & 1 & 1 & 1 & 1 \\
Individuals & 98 & 47 & 32 & 17 & 23 & 19 \\
Dominance D & 1 & 1 & 1 & 1 & 1 & 1 \\
Shannon H & 0 & 0 & 0 & 0 & 0 & 0 \\
Simpson_1-D & 0 & 0 & 0 & 0 & 0 & 0 \\
${\text { Evenness } \mathrm{e}^{\wedge} \mathrm{H} / \mathrm{S}}_{\text {Margalef }}^{1}$ & 1 & 1 & 1 & 1 & 1 \\
\hline
\end{tabular}

The Family Scianidae is also one of the economic species in Badagry, individual species has relative high abundance with Evenness index close to one, and Simpson's index takes into account the diversity of species present with minimum value of 1.09 in August (Table 10).

Table 10. Showing the ecological indices of the species composition of Family Scianidae.

\begin{tabular}{lllllll}
\hline & April & May & June & July & August & September \\
\hline Species & 4 & 4 & 4 & 4 & 4 & 4 \\
Individuals & 379 & 407 & 249 & 207 & 118 & 43 \\
Dominance_D & 0.3523 & 0.3325 & 0.3689 & 0.3303 & 0.3851 & 0.3261 \\
Shannon_H & 1.148 & 1.167 & 1.105 & 1.216 & 1.09 & 1.216 \\
Simpson_1-D & 0.6477 & 0.6675 & 0.6311 & 0.6697 & 0.6149 & 0.6739 \\
Evenness_e^H/S & 0.7876 & 0.8028 & 0.755 & 0.8435 & 0.7439 & 0.8434 \\
Margalef & 0.5053 & 0.4993 & 0.5437 & 0.5626 & 0.6288 & 0.7976 \\
\hline
\end{tabular}

The Family Heamulidae is also one of the obserced species in Badagry beach seine catch, individual species has relative high abundance with Evenness index close to 1, and Simpson's index takes into account the diversity of species present with minimum value of 0.14 in August and 0.68 in April (Table 11).

Table 11. The ecological indices of the species composition of Family Haemulidae.

\begin{tabular}{lcccccc}
\hline & April & May & June & July & August & September \\
\hline Species & 2 & 2 & 2 & 2 & 2 & 2 \\
Individuals & 293 & 230 & 139 & 115 & 63 & 39 \\
Dominance_D & 0.5042 & 0.5667 & 0.8304 & 0.6062 & 0.9385 & 0.5161 \\
Shannon_H & 0.6889 & 0.6249 & 0.3106 & 0.5828 & 0.1408 & 0.677 \\
Simpson_1-D & 0.4958 & 0.4333 & 0.1696 & 0.3938 & 0.06148 & 0.4839 \\
Evenness_e^H/S & 0.9958 & 0.934 & 0.6821 & 0.8955 & 0.5756 & 0.9839 \\
Margalef & 0.1761 & 0.1839 & 0.2027 & 0.2108 & 0.2414 & 0.273 \\
\hline
\end{tabular}


The Family Mullidae is also one of the observed species in Badagry beach seine catch, individual species has relative high abundance with Evenness index, range 0.90, 0.96, 0.98, 1.00 and
0.92 but 0.66 in June. Shannon's index takes into account the diversity of species present with minimum value of 0.28 in August and maximum value of 0.67 in July (Table 12 ).

Table 12. Showing the ecological indices of the species composition of Family Mullidae.

\begin{tabular}{lllllll}
\hline & April & May & June & July & August & September \\
\hline Species & 2 & 2 & 2 & 2 & 1 & 2 \\
Individuals & 7 & 56 & 48 & 15 & 11 & 23 \\
Dominance_D & 0.59 & 0.53 & 0.84 & 0.52 & 1 & 0.57 \\
Shannon_H & 0.59 & 0.66 & 0.28 & 0.67 & 0 & 0.61 \\
Simpson_1-D & 0.40 & 0.46 & 0.15 & 0.48 & 0 & 0.42 \\
Evenness_e^H/S & 0.90 & 0.96 & 0.66 & 0.98 & 1 & 0.92 \\
Margalef & 0.51 & 0.248 & 0.25 & 0.36 & 0 & 0.31 \\
\hline
\end{tabular}

The frequency of operation in each fishing company shows how often each of them goes for fishing. The level operations depend on clarity of the water body, availability of labour and so on. Baba Agba Fishing Company has highest fishing in April and July while the lowest was in September. Kwami Kotokpa Fishing Company has highest of operation in April and lowest in August. Hope Fishing Company has the highest operation in May while the lowest in September. $\mathrm{Mr}$ Yovoyan Fishing Company has the highest level of operation in May and lowest in September. Boglo Fishing Company has highest and lowest in July and June, respectively (Figure 6).

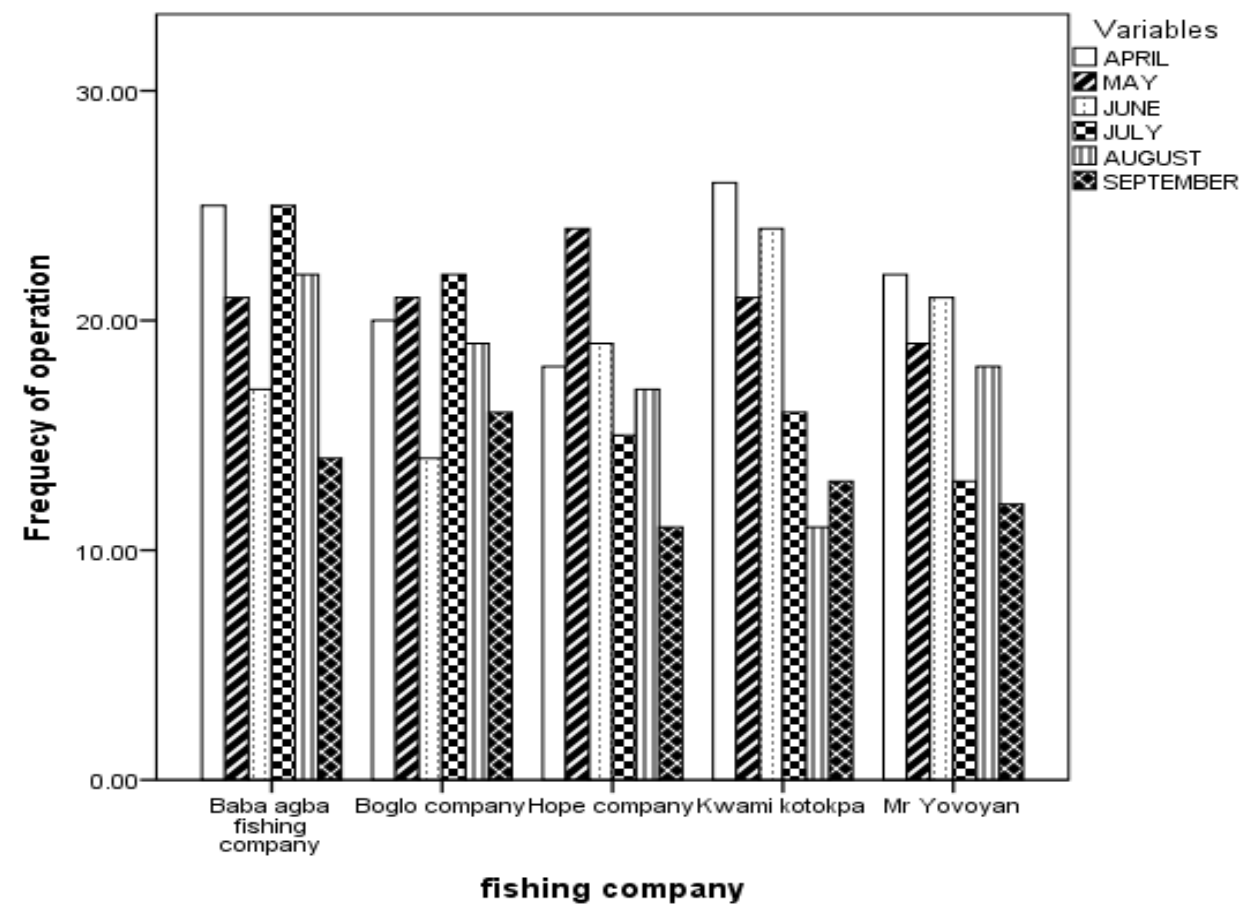

Figure 6. Analysis of frequency of operation for each fishing company. 
This shows how frequent the fishing companies go for fishing in each month. The mean monthly frequency of operation in April was $22.20 \pm 1.49$ while May was 21.20 \pm 0.80 . The monthly mean from June was $19.00 \pm 1.70$. July mean was $18.20 \pm 2.26$.
August and September were $17.40 \pm 1.80$ and $13.20 \pm 0.86$ respectively. In the month of September there was minimum frequency of fishing due to fact that the companies repair their beach seine nets (Table 13).

Table 13. Mean \pm standard error, standard deviation and minimum and maximum frequency of operation for the fishing companies from April to September.

\begin{tabular}{lcccccc}
\hline & April & May & June & July & August & September \\
\hline Mean & 22.20 & 21.20 & 19.00 & 18.20 & 17.40 & 13.20 \\
Std. Error of Mean & 1.49 & 0.80 & 1.70 & 2.26 & 1.80 & 0.86 \\
Std. Deviation & 3.34 & 1.78 & 3.80 & 5.06 & 4.03 & 1.92 \\
Minimum & 18.00 & 19.00 & 14.00 & 13.00 & 11.00 & 11.00 \\
Maximum & 26.00 & 24.00 & 24.00 & 25.00 & 22.00 & 16.00 \\
\hline
\end{tabular}

The catch level of Baba Agba Fishing Company had 1,005.6 kg in April, $837.6 \mathrm{~kg}$ in May. $1,114 \mathrm{~kg}$ in June 761.7 $\mathrm{kg}$ in July while $476 \mathrm{~kg}$ and $330 \mathrm{~kg}$ in August and September. Kwami Kotokpa Fishing Company were 670 kg, 763.2 kg,
$781 \mathrm{~kg}, 952 \mathrm{~kg}, 440.6 \mathrm{~kg}$ and $251 \mathrm{~kg}$ from April to September. Hope Fishing Company had minimum catch of $354 \mathrm{~kg}$ in August and highest catch in June with catch of $980 \mathrm{~kg}$ (Table 14).

Table 14. The catch level for each of the fishing company (kg).

\begin{tabular}{|c|c|c|c|c|c|c|}
\hline Company & April & May & June & July & August & September \\
\hline Baba Agba Fishing Company & $1,005.6$ & 837.6 & 1,114 & 761.7 & 476 & 330 \\
\hline $\begin{array}{l}\text { Kwami Kotokpa Fishing } \\
\text { Company }\end{array}$ & 670 & 763.2 & 781 & 962 & 440.6 & 251 \\
\hline $\begin{array}{l}\text { Hope Fishing Company At } \\
\text { Asakpo }\end{array}$ & 605.6 & 876.4 & 980 & 790 & 354 & 480 \\
\hline $\begin{array}{l}\text { Mr Yovoyan Fishing } \\
\text { Company }\end{array}$ & 908 & 638 & 1,013 & 823 & 616 & 270 \\
\hline Boglo Fishing Company & 716 & 851 & 802 & 590 & 653.4 & 543 \\
\hline
\end{tabular}

The mean catch in of the companies in April was $781.04 \mathrm{~kg} \pm$ $75.46 \mathrm{~kg}$, while for May was $793.24 \mathrm{~kg} \pm$ $43.14 \mathrm{~kg}, 938.00 \mathrm{~kg} \pm 63.83 \mathrm{~kg}$ in June,
$785.34 \mathrm{~kg} \pm 59.73 \mathrm{~kg}$ July, and lastly $508.00 \mathrm{~kg} \pm 55.71 \mathrm{~kg}$ and $374.80 \mathrm{~kg} \pm$ $58.16 \mathrm{~kg}$ in August and September, respectively (Table 15).

Table 15. The mean and standard error, standard deviation and range with its lowest value and highest value of the weight from April to September in $\mathrm{kg}$.

\begin{tabular}{lcccccc} 
& April & May & June & July & August & September \\
\hline Mean & 781.04 & 793.24 & 938.00 & 785.3400 & 508.00 & 374.80 \\
Std. Error of Mean & 75.46 & 43.14 & 63.83 & 59.73 & 55.71 & 58.16 \\
Std. Deviation & 168.73449 & 96.46434 & 142.74 & 133.57143 & 124.58724 & 130.07190 \\
Minimum & 605.60 & 638.00 & 781.00 & 590.00 & 354.00 & 251.00 \\
Maximum & 1005.60 & 876.40 & 1114.00 & 962.00 & 653.40 & 543.00 \\
\hline
\end{tabular}


The catch level of Baba Agba Fishing Company was $1,005.6 \mathrm{~kg}$ in April, $837.6 \mathrm{~kg}$ in May. $1,114 \mathrm{~kg}$ in June which was the highest of the company's catch and $761.7 \mathrm{~kg}$ in July while $476 \mathrm{~kg}$ and $330 \mathrm{~kg}$ in August and September, respectively. Kwami Kotokpa Fishing Company catches were $670 \mathrm{~kg}, 763.2 \mathrm{~kg}$, $781 \mathrm{~kg}, 952 \mathrm{~kg}, 440.6 \mathrm{~kg}$ and $251 \mathrm{~kg}$ from
April to September. Hope Fishing Company had minimum catch of $354 \mathrm{~kg}$ in August and highest catch in June with catch of $980 \mathrm{~kg}$. The companies had reduced catches in September due to lower frequency of operation except Hope Fishing Company which had the lowest catch of $354 \mathrm{~kg}$ in August (Figure 7).

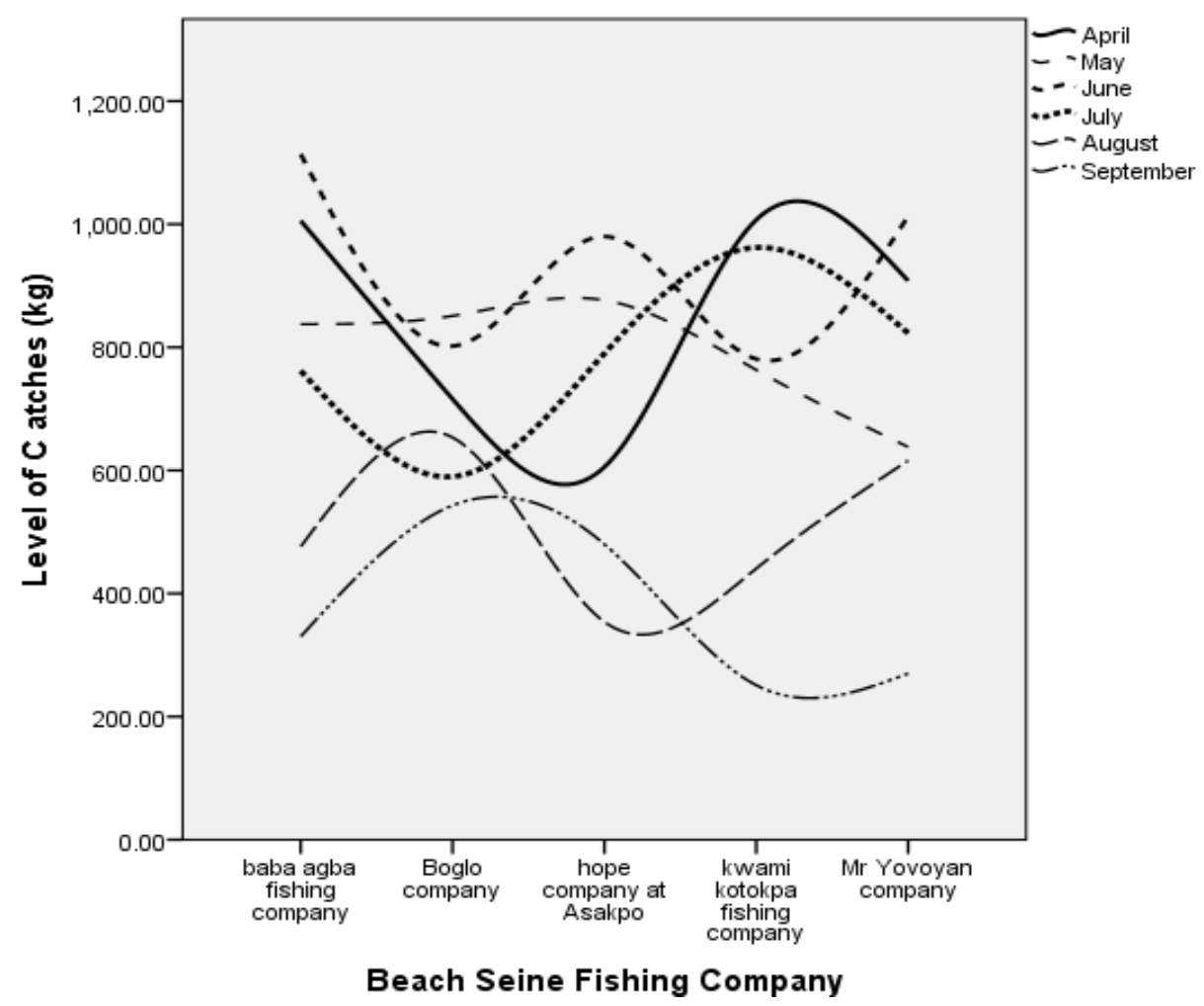

Figure 7. Catch level of each fishing company from April to July.

Baba Agba Fishing Company had mean monthly catch of $754.03 \pm 123.423$ $\mathrm{kg}$, Kwami Kotokpa fishing company had $644.50 \mathrm{~kg} \pm 105.00 \mathrm{~kg}, 680.83 \mathrm{~kg} \pm 98.72$ $\mathrm{kg}$ for Hope Fishing Company, $711.33 \mathrm{~kg}$ $\pm 108.22 \mathrm{~kg}$ and $692.56 \mathrm{~kg} \pm 49.00 \mathrm{~kg}$ for Mr Yovoyan Fishing Company and Boglo Fishing Company, respectively (Table 16).

Table 16. Mean weight with standard deviation and standard error of mean.

\begin{tabular}{lccc}
\hline Company & Mean (kg) & Std. Deviation & Std. Error Mean \\
\hline Baba Agba fishing company & 754.03 & 302.32 & 123.42 \\
Kwami Kotokpa & 644.50 & 257.21 & 105.00 \\
Hope Company & 680.83 & 241.83 & 98.72 \\
Mr Yovoyan company & 711.33 & 265.10 & 108.22 \\
Boglo company & 692.56 & 120.04 & 49.00 \\
\hline
\end{tabular}


The mean monthly income of Baba Agba Fishing Company for the study period was $\$ 235,333.33 \pm$ \#38,486.24, Kwami Kotokpa Fishing Company income was $\$ 171,978.33 \pm$ \#20,199.78, Hope Fishing Fishing
Company income was $\$ 212,575.00 \pm$ \#23,601.91, $\mathrm{Mr}$ Yovoyan Fishing Company and Boglo Fishing Company were $\$ 245,341.66 \pm \$ 27,791.04$ and \#226,796.66 $\pm \$ 12,660.07$, respectively (Table 17).

Table 17. The mean, standard error, standard deviation, minimum and maximum range of income of each fishing company from April to September.

\begin{tabular}{lccccc}
\hline & $\begin{array}{c}\text { Baba Agba } \\
\text { Fishing } \\
\text { Company (\#) }\end{array}$ & $\begin{array}{c}\text { Kwami } \\
\text { Kotokpa } \\
\text { Fishing } \\
\text { Company (\#) }\end{array}$ & $\begin{array}{c}\text { Hope Fishing } \\
\text { Company (N) }\end{array}$ & $\begin{array}{c}\text { Mr Yovoyan } \\
\text { Fishing } \\
\text { Company (\#) }\end{array}$ & $\begin{array}{c}\text { Boglo } \\
\text { Fishing } \\
\text { Company (\#) }\end{array}$ \\
\hline Mean & $235,333.33$ & $171,978.33$ & $212,575.00$ & $245,341.66$ & $226,796.66$ \\
Std. Error of Mean & $38,486.23$ & $20,199.78$ & $23,601.91$ & $27,791.04$ & $12,660.07$ \\
Std. Deviation & $94,271.64827$ & $49,479.17559$ & $57,812.65216$ & $68,073.87470$ & $31,010.72180$ \\
Minimum & $119,200.00$ & $93,200.00$ & $126,350.00$ & $134,700.00$ & $192,700.00$ \\
Maximum & $369,650.00$ & $223,800.00$ & $267,000.00$ & $332,300.00$ & $265,500.00$ \\
\hline
\end{tabular}

The mean income of individual fishing companies in Badagry. There was variation in the income of the beach seine throughout the period of the study.
Baba Agba Fishing Company had highest mean income during the study and Kwami Kotokpa Fishing Company had lowest mean income (Figure 8).

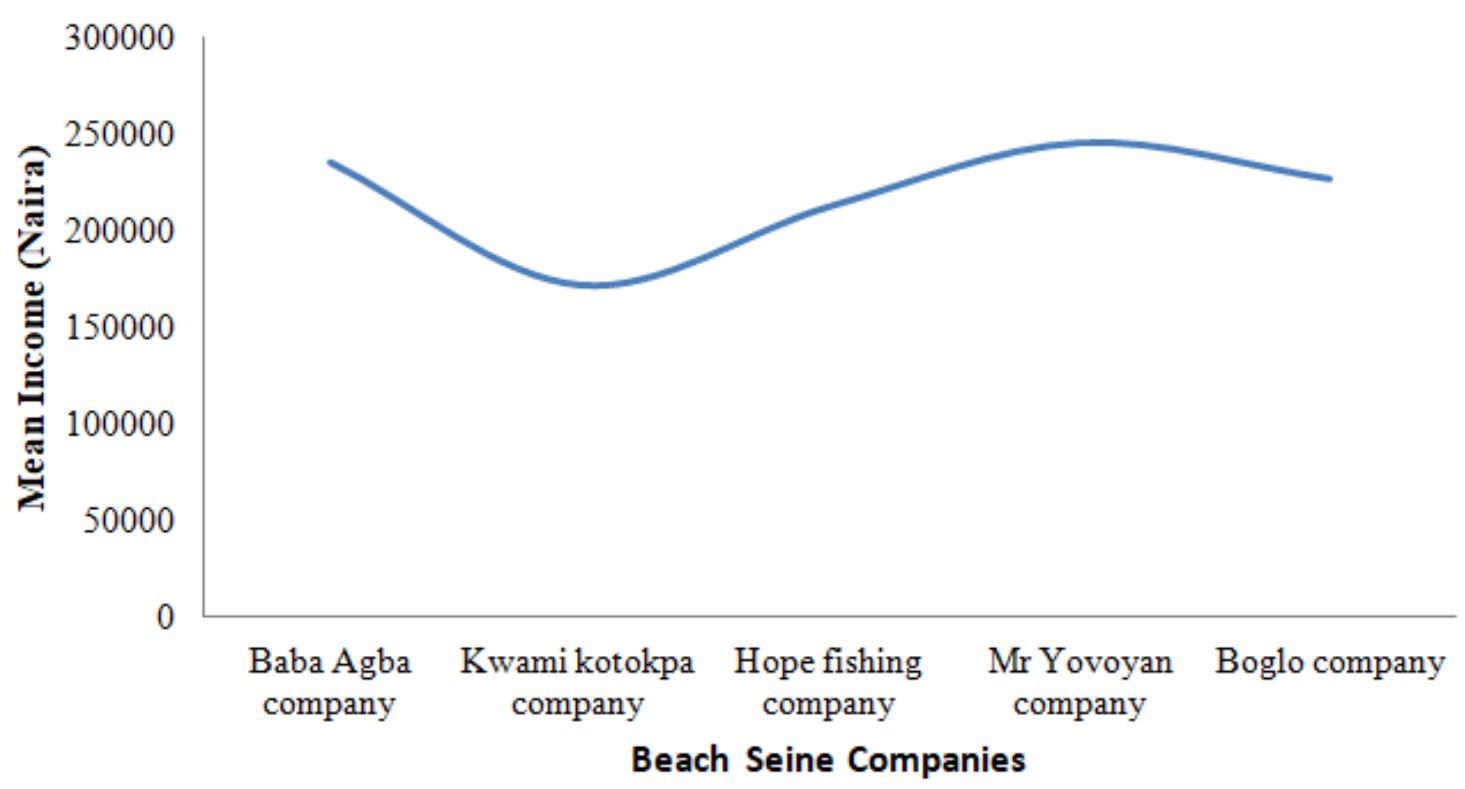

Figure 8. A chart showing the mean income of beach seine companies in Badagry $((1 \mathrm{~A}=\$ 0.0032)$. 
Number of crew in the study area varied from one fishing company to another. The Figure 9 shows the number of crew in each fishing company in Badagry during the study. The number crew in Baba Agba Fishing Company,
Boglo Fishing Company and Kwami Kotokpa Fishing Company had 20 crew members. Hope Company had the highest number of crew of 30 followed by Mr Yovoyan Fishing Company with 25 crew members (Figure 9).

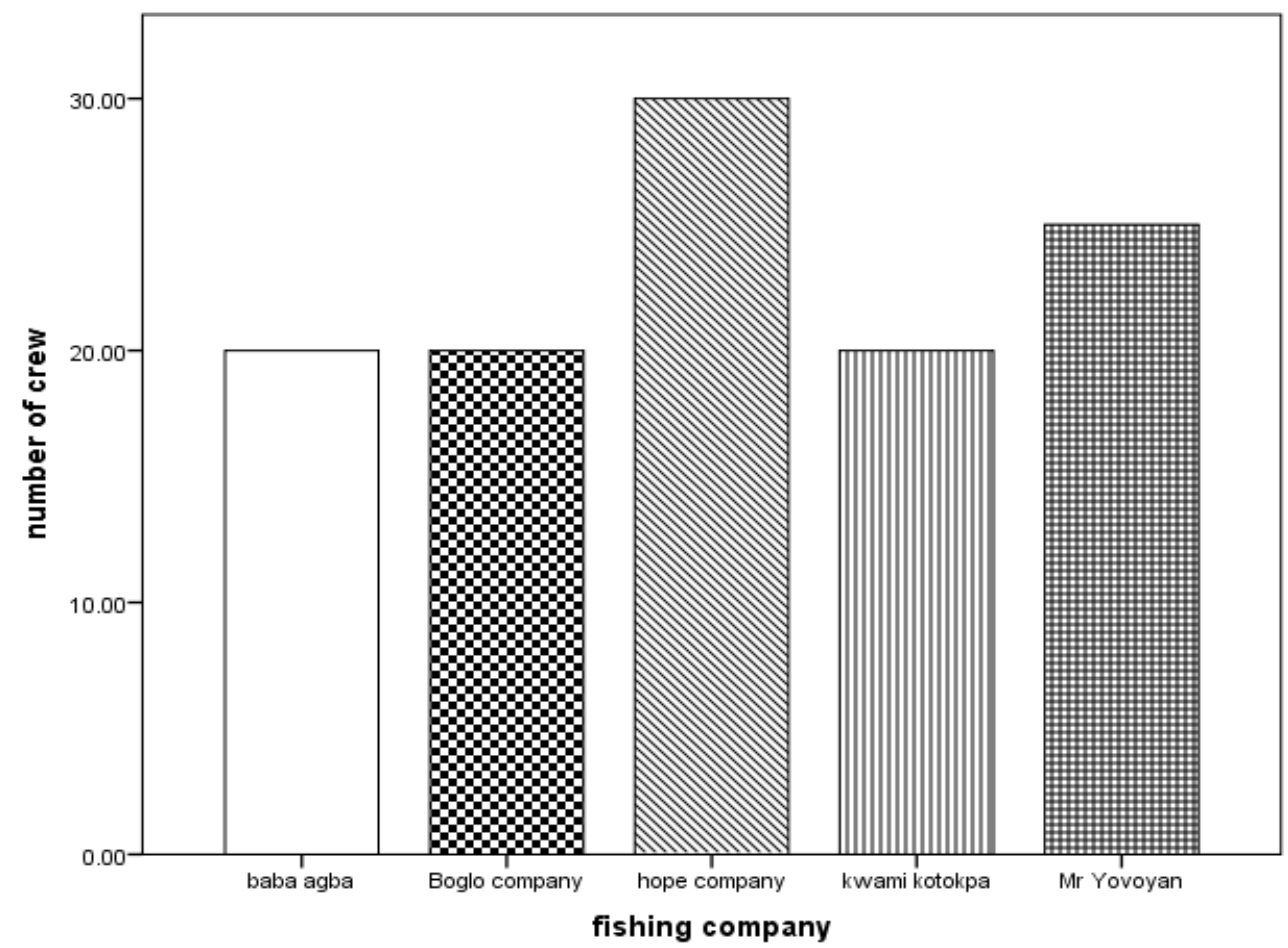

Figure 9. Showing the number of crew per beach seine company.

\section{Distribution of catch}

The distribution of catch depended on the total catch, gears, vessel ownership, and the crew size. The fish traders bought $75 \%-100 \%$ of the entire catch while fresh, with an average of $10 \%-20 \%$ was retained for crew and the gear/boat owner. In all five companies, the owner takes $20 \%$ of the entire sale of fish. Obviously, the larger the crew size, the lower the individual benefit per fisher is. $5 \%$ or less is use as gift (Figure 10). 


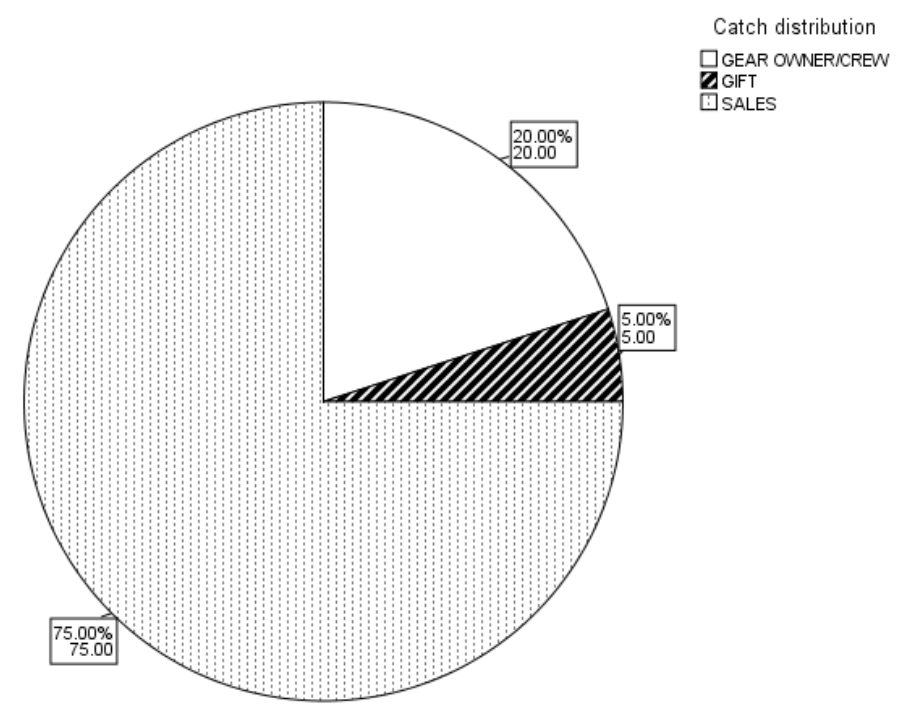

Figure 10. The distribution percentage of beach seine catch in Badagry.

\section{Sociodemograpic variables of badagry fisher folks}

Entries from the descriptive analysis of socioeconomic characteristics of respondents in the study area show that: Age is an important socioeconomic characteristic because it affects productivity, output and adoption of innovation. People aged between 21-30 were $20 \%$, while people aged between $31-40$ were $36 \%$ which was the highest age class in the study area followed by people with age class of 41-50 with 28\%. People who were aged between 51-60 and over 60 years of age were $12 \%$ and $2 \%$.

Gender is also an important part of socio economic parameter of beach seine fishermen in Badagry. Although female also help in hauling was insignificant. But their major role include packing of the hauling rope, giving out refreshment to crew members, packing of the net, marketing and processing of excess catch. The male percentage was $94 \%$ and $6 \%$ female.

Marital status affect migration of fishermen, it may affect labour availability since beach seine fishermen use family labour. $8 \%$ of the people in the study area were divorced, while 56\% were married and $36 \%$ were single.

Level of education will help in packaging and taking of record of their expenses, income and other activities which would have develop the beach seine artisanal fishing sector. Adoption of technology and innovation would also be affected by their literacy level. The level of education of beach seine fishermen in Badagry where $21 \%$ had no formal education, $45 \%$ with primary education, $34 \%$ had secondary school education and $5 \%$ had tertiary education (Figure 11). 


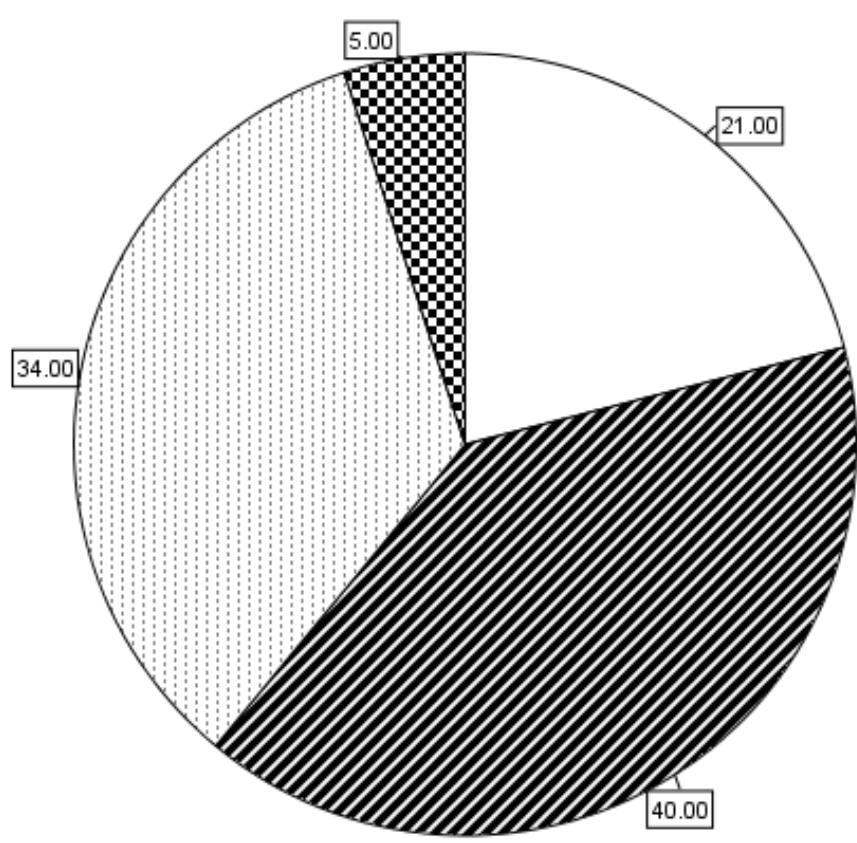

LEVEL OF

EDUCATION

NNO FORMAL EDUCATION

UPRIMARY EDUCATON

G SECONDARY EDUCATION

GTTIARY

Figure 11. Showing demographic representation educational level of beach seine fisher folks.

Nationality brings about language barrier among the beach seine fishermen in dealing with other individual in the community, their customers and even researchers. Though long stay of the nonNigerians has in improve their relationship with others. In the study area there were $42 \%$ Ghanaians and 58\% Nigerians.

\section{Discussion}

\section{Description of beach seine net}

A majority of the surveyed beach seine had mean length of $301.763 \pm$ 17.82 and the depth at wing measured $2.80 \mathrm{~m} \pm 0.14 \mathrm{~m}$ while the depth at the centre had mean of $4.02 \mathrm{~m} \pm 0.22 \mathrm{~m}$. The mesh size tapered towards the cod end at different part of the net.

The mean mesh size of the fore wing, body and cod end mesh sizes are $50.00 \mathrm{~mm} \pm 2.00 \mathrm{~mm}, 26.00 \pm 1.00 \mathrm{~mm}$ and $10.00 \pm 0.63$. Emmanuel (2010) opined that the mesh sizes of the nets are good indicator of the status of exploitation level of water. The results show that the fore wings had the larger mesh size ranging from 50 to $60 \mathrm{~mm}$. The body had mesh sizes varying from 25 to $30 \mathrm{~mm}$. while the cod end had finer mesh of 8 to $12 \mathrm{~mm}$. The bag portion was long, but the majority ranged from 10 to 20 meters with a depth of $6 \mathrm{~m}$. Chindah et al. (2001) opined that gillnets have mesh sizes vary from $35 \mathrm{~mm}$ to $70 \mathrm{~mm}$.

\section{Frequency of operations from April to September \\ Table 5 from the result revealed} that the mean monthly frequency of operation from April to September. The mean frequency of operation in April for the fishing companies is $22.20 \pm$ 1.49 while in May was $21.20 \pm 0.80$. In June, the frequency of operation was $19.00 \pm 1.70$. In July, the mean frequency of operation was $18.20 \pm 2.27$ while for August and September were $17.40 \pm 1.81$ and $13.20 \pm 0.86$ respectively Most of the other days were used in the maintenance of the net, boat, Outboard engine etc. 


\section{Beach seine catch composition}

Fish abundance, diversity and dominance were mainly related to fishing gear type with beach seine higher proportions due to its non-selectivity and higher number of nets joined together. The moon fish (Carangidae), croaker fish (Scianidae) and spadefish (Eppiphidae) families represented more than half of the daily landings. These were followed by sardine (Clupeidae) and barracuda (Sphyraena). Table 3 provides a species list of all catches that were sampled.

From Table 6 the Family Carangidae has the abundance of $76 \%$ in September and the lowest abundance of $46 \%$ in May. Table 7 which comprise sole species has 95\% abundance in April and abundance of $78 \%$ in September. The relative abundance of Family Scianidae is high in July and September which were $84 \%$ and $74 \%$ in August.

\section{Level of catch for the beach seine fisheries}

The mean catch recorded ranged for the company range from minimum of $644.50 \mathrm{~kg} \pm 98.72 \mathrm{~kg}$ to maximum of $754.03 \mathrm{~kg} \pm 123.523 \mathrm{~kg}$ from April to September. The maximum catch occurred at least in month while the minimum catch occurred three times in a month. For the most part of the month catches fluctuated depending on the season and the company.

\section{Level of catches}

From Table 15, the mean monthly catch in April was 781.04 \pm 75.4603 with minimum range of 605.60 and maximum range was 1,005.60.793.24 \pm 43.1401 was recorded in May which ranges from 638.00 to $876.40 .938 .000 \pm 63.8396$ was gotten in June that range from 781.00 to 1114.00. The mean catch in July was $785.3400 \pm 56.7349$ and ranges from 590.00 to 962.00 while $508.00 \pm 55.71$ and 374.80 were gotten in August and September, respectively.

\section{Income of the beach seine fisher folks}

The projected income for the beach seines was determined by working with the number of beach seine crews, the monthly mean and the number of days fished in a month. With the market price for fish that range from $\$ 1,000$ to $\$ 5,000$ per basin, the income of the beach seine companies from Table 17, Baba Agba Company recorded mean income of N235,333.33 $\pm 38,486.23$ for the period of six months, while kwami kotokpa Fishing Company recorded mean income (in Nigerian Naira $\#$ ) of $\$ 171,978.33 \pm$ \#20,199.78. Hope fishing company entered $\$ 212,575.00 \pm \$ 23,601.91$. $\mathrm{Mr}$ Yovoyan Company $\$ 245,341.67 \pm \$ 67.00$ and Boglo fishing company recorded mean monthly income of $\$ 226,796.67 \pm$ N12,660.07.

\section{Sociodemographic values}

It was obtained from the survey that $20 \%$ of the respondents' ages in the study area are between 21 and 30 years follow $37 \%$ of age between 31 to 40 years while $29 \%$ are between 41 to 50 years and $12 \%$ are between 51 to 60 years and just $2 \%$ are above 61 years. The study also revealed that there was no much disparity between each category of fishing experience which implied that the possibility of smooth transition of the trade from one generation to another was high. This implies that most people engaged in fish catching were still active and physically fit to haul the beach seine for several hours and paddle the canoes. The implication was that the respondents are within the productive and economic active age, and could be able to increase fish catch and improve livelihood of the families. The finding was in agreement with those of Olaoye (2010), who found that most of the fisher folks are in their economic active ages to undertake 
strenuous task associated to the fishing enterprise and also in line with Bello (2000) ascertain that age has positive correlation with acceptance of innovation and risk taking. This also agrees with the observations of Okayi et al. (2013) who reported that fishing was practiced by youths of both sexes but with a preponderance of males in their study area. The hazards and rigors involved in fishing activities may be the reason why less number of female, children and old age brackets were involved in gillnets fishing.

Of the total 50 respondents, $94 \%$ were found to be males while $6 \%$ were female. This is a throwback to the belief on women acess to productive resources of which credit is one; this is contrary to Lahai et al. (2000), which suggest that women participated more than man in most farming activities. Fishing practices are not limited to a particular gender both male and female are engage in capture fisheries to increase fish production, income level and improve food security of the economy. It was seen in the study area that a larger proportion of the fisher folks $(36 \%)$ were single, $56 \%$ were married and $8 \%$ were divorced. This implies that occupational mobility will be not reduced but may affect family labour that should be available for collective responsibility.

The distribution of level of education as shown in Figure 11 shows that about $21 \%$ of the fishermen, who were involved in beach seine fisheries, had no formal education, while $40 \%$ primary education. It equally revealed that $34 \%$ of the fishermen had secondary education as just $5 \%$ had tertiary education. This implies that majority of the farmers in the study area had one form of education or the other which could assist them in the area of adoption of innovations brought to them by the extension agents and in making decisions that will enhance their marketing strategies.

Also it was noticed that in the study area majority of the respondents were Nigerian (58\%) while the remaining were Ghanaian (42\%). This made communication easy amongst the fisher folks.

\section{Conclusion}

Nigeria's fisheries resources have potentials of withstanding sustained exploitation under effective management from regulation of fishing efforts and capacity to exploit aquatic resources optimally. The coastal artisanal fishery is still able to absorb a little more effort and capacity to enable production meet up with the potential yield. It is however essential in the national interest that there should be a clear understanding of fishing capacity development on capital, labour and fish resources, both in the short and long term. The choice of the most appropriate combinations is not easy since the benefits, both direct and indirect, will be distributed in different ways. In some cases, the sustenance or increase of the revenue to fishermen and contributions to the economy are paramount. In others, the choice is to develop fisheries beach seine fisheries as a means for meeting social objectives and increasing the opportunities for employment. Technological advancement is also needed to develop the coastal artisanal fisheries especially beach seine fisheries to make the fish exploitation easier and the output in term of the catches and income of the beach seine fishermen.

\section{Conflict of interest}

Authors declare that they have no conflict of interests.

\section{References}

Bello, M. O. Categorization of potential adopters for organic based fertilizer among vegetable farmers in Ojo LGS State. Abeokuta: University of Agriculture, 2000. 
Brandt A. Fish catching methods of the world. 3. ed. Farnham and Surrey, England: Fishing News Books, 1984.

Emmanuel, B. E. Assessment of fishing practices in a tropical low brackish lagoon ecosystem in south western Nigeria. Acta SATECH, v. 3, no. 2, p. 69-80, 2010. Available from: <http://www.actasatech.com/ index.php?q=journal.view.101>. Accessed on: Sept. 23, 2018.

FDF-Federal Department of Fisheries. Report of Presidential Committee on Fisheries and Aquaculture Development. Consolidated report. September, 2005. v. 1.

Federal Republic of Nigeria Official Gazette. 2007. Available from: <http://www.nigerian stat.gov.ng/Connections/Pop2006.pdf>.

Accessed on: Sept. 23, 2018.

FAO-Food and Agriculture Organization. Technical Guidelines for Responsible Fisheries. Increasing the Contribution of Small-Scale Fisheries to Poverty Alleviation and Food Security. 2005.

Gabriel, O.; Lange, K.; Dahm, E.; Wendt, T. Von Brandt's fish catching methods of the world. 4. ed. Oxford, UK: Blackwell, 2005.

Lagos State Gazette. Lagos State Government Official Gazette. September Issue. 2009.

Okayi, R. G.; Solomon, S. G.; Ataguba, A. G.; Chukwudi, O. P.; Mbata, F. U. Indigenous knowledge of shrimps and prawn species and fishing of the Benue and Niger River (middlebelt savannah) - Nigeria. Agriculture and Biology Journal of North America, v. 4, no. 3, p. 221-226, 2013. https://doi.org/ 10.5251/abjna.2013.4.3.221.226

Olaoye, 0. J. Dynamics of the adoption process of improved fisheries technologies in Lagos and Ogun States, Nigeria. Ogun State, Nigeria: University of Agriculture Abeokuta, 2010. (Ph. D. thesis).

License information: This is an open-access article distributed under the terms of the Creative Commons Attribution License, which permits unrestricted use, distribution, and reproduction in any medium, provided the original work is properly cited. 